\title{
Bacteria contamination and Cadmium heavy metal content of blood coockle (Anadara granosa Linn) satay on street vendors in Surabaya, Indonesia
}

\author{
Ratna Yulistiani $^{1^{*}}$, Erwan Adi Saputro ${ }^{2}$, Dadik Raharjo ${ }^{3}$ \\ ${ }^{1}$ Food Technology Department, Faculty of Engineering, University of Pembangunan Nasional "Veteran" Jawa \\ Timur, Indonesia \\ ${ }^{2}$ Chemical Engineering Department, Faculty of Engineering, University of Pembangunan Nasional "Veteran" Jawa \\ Timur, Indonesia \\ ${ }^{3}$ Faculty of Veterinary Medicine, Airlangga University, Indonesia
}

\begin{abstract}
This study aims to detect the food safety of blood coockle satay sold by street vendors in Surabaya Indonesia, in terms of bacterial contamination and Cadmium heavy metal content. This research is descriptive research with survey method. The sampling technique was carried out randomly from 15 street vendors, for further testing of bacterial contamination which included total bacteria, Coliform bacteria, and detection of heavy metal Cadmium $(\mathrm{Cd})$ in blood coockle satay. The results showed that of all (15) satay samples studied have the average total microbes was 7.22 Log CFU/gr, Coliform bacterial contamination exceeded the maximum limit determined by the food regulatory agency Food and Drug Supervisory Agency of Republic Indonesia in 2009 ((>3 MPN/gram). As many as 5 (33.33\%) of the 15 samples of scallop satay containing heavy metal Cd exceeded the maximum limit determined by Food and Drug Supervisory Agency of Republic Indonesia in 2017 (>0.1 mg/kg).
\end{abstract}

Keywords: Safety Food, Bacterial Contamination, Cadmium Heavy Metal

\section{Introduction}

Food safety is a condition and effort needed to prevent food from being contaminated by biological, chemical, and other objects that can interfere, harm, and endanger human health and do not conflict with religion, belief, and community culture so that it is safe for consumption [1]. There are three hazards that need to be watched out for in relation to food safety, namely microbiological hazards, chemical hazards, and physical hazards. Microbiological hazards include pathogenic bacteria, viruses, and parasites [2].

Surabaya has a special food "Blood coockle satay" made from blood coockle meat, which in the manufacturing process is not baked or grilled like other satays, but boiled and usually served as a complement to "Lontong Balap" and "Lontong Kupang". Blood coockle satay must meet health requirements including adequate nutritional content, free from heavy metals and microorganisms that can interfere with health [3].

Besides having high nutritional content, blood coockle also have the ability to accumulate heavy metals compared to other marine animals. Several studies on the heavy metal content of Cadmium in blood coockle have been carried out by [4], [5] and [6]. According to [7] the content of Cadmium in blood coockle originating from Kenjeran waters exceeds the threshold set by [8] regarding Cadmium metal contamination ( 0.1 ppm), while the average Cadmium heavy metal content in blood coockle is $0.301 \mathrm{ppm}$. Cadmium $(\mathrm{Cd})$ is a heavy metal group with high toxicity. According to [9], due to heavy metal poisoning $\mathrm{Cd}$ causes damage to the liver, kidneys, lungs, bones, and is a carcinogen. According to the Regulation of the Food and Drug Supervisory Agency No 5 in 2018 concerning the maximum limit of Cadmium heavy metal contamination in fish and shellfish processed foods that may be consumed, which is $0.10 \mathrm{ppm}$.

Heavy metals have been shown to suppress the immune system resulting in a decrease in the number of antibody-producing cells, which will increase the body's susceptibility to bacteria, parasites, and viruses as well as susceptibility to cancer [10] and [11]. Heavy metal contamination in food products must be removed or reduced in order to make the product safe for consumption. Processing of foodstuffs before consumption is very important to reduce/eliminate

* Corresponding author : ratnayulistiani@yahoo.co.id 
levels of heavy metals in foodstuffs. [12], showed that there is a decrease in the content of heavy metals $\mathrm{Cd}$, $\mathrm{Cu}, \mathrm{Zn}$ and $\mathrm{Fe}$ in blood clams (Anadara granosa) during the process of making and reheating scallop satay. [13], also suggested that processing by steaming, boiling and sauteing can reduce the levels of heavy metals $\mathrm{Pb}$ and $\mathrm{Cd}$ in the leaves and fruit of long beans.

Blood coockle satay is traditionally cooked and sold ready-to-eat. Traditional processing causes differences in maturity, hygiene, sanitation and food safety among traders. There is a time lag between the scallop satay when consumed by consumers and processing. Scallop satay is displayed at room temperature before consumption, thus allowing for bacterial contamination from the environment where it is sold. Pathogenic bacteria in scallop satay may come from contamination of scallops that are not destroyed due to processing, cross-contamination of raw scallops due to poor hygiene and sanitation as well as during the scallop satay on display before consumption.

[14], showed that E. coli contamination in blood clam satay sold in the Surabaya traditional market area exceeded the SNI threshold. The results of research that researchers have done previously [15], showed that the environmental sanitation conditions of sales in traditional markets in Surabaya affect the level of contamination of pathogenic bacteria in chicken meat. Food safety related to the dangers caused by bacteria is measured by two main parameters, namely: the number of polluting bacteria and the type of pathogenic bacteria. One way to determine the level of food hygiene and sanitation is to use a microbiological analysis method which includes the calculation of total bacteria (Total Plate Count), total Coliform and total E. coli which are used as indicators of faecal contamination [16]. This study aims to detect the food safety of blood coockle satay sold by street vendors in Surabaya Indonesia, in terms of bacterial contamination and Cadmium heavy metal content.

\section{Research Methods}

This is descriptive research with survey method. The sampling technique was done randomly. A total of 15 samples of blood coockle satay were obtained from 15 street vendors in the Kenjeran area of Surabaya. The research methods included observation on hygiene and sanitation from 15 scallop satay traders, microbiological test of blood coockle satay which included total bacteria as an indicator of contamination level and total Coliform test with the Most Probable Number (MPN) method and analysis of Cadmium heavy metal content.

\subsection{Determination of Total Bacteria (Drop Methods)}

A total of $25 \mathrm{~g}$ samples were mixed using a stomacher machine for 2 minutes. One gram of the sample was weighed and homogenized in $9 \mathrm{ml}$ of Buffered Peptone Water (BPW, Oxoid, Wesel, Germany) to produce a $10^{-1}$ dilution, then a $10^{-2} 10^{-3} 10^{-4} 10^{-5} 10^{-6}$ and so on with $0.1 \%$ Peptone Water solution. For each sample, 50 $\mu 1$ of each dilution was taken with a micropipette and dripped onto the surface of a fairly dry sterile Plate
Count Agar (PCA) media. PCA was incubated overnight (18-24 hours) at $37^{\circ} \mathrm{C}$. Colony growth was counted using the Colony Counting Chamber and calculated in Colony Forming Units per gram (cfu/g) of meat sample using the formula :

$\mathrm{Cfu}=$ number of colonies $\mathrm{x} 1000 / 50 \times$ dilution factor

Henceforth, it is expressed in colony-forming units on average per gram (average $\mathrm{cfu} / \mathrm{g}$ ) and converted to $\log$ 10 (Yulistiani et al., 2019).

\subsection{Total Coliform with Most Probable Number (MPN) Methods}

MPN is a microorganism enumeration method that uses data from the growth of microorganisms in a specific liquid medium in a series of tubes grown from solid or liquid samples so as to produce a range of the number of microorganisms in the closest approximate number. Coliform bacteria fermented with lactose media will produce gas if incubated for more than 48 hours at $35^{\circ} \mathrm{C}$. The basis of the MPN method is by looking at the gas produced in the test tube which is then adjusted to the MPN table [17].

\subsubsection{Presumptive Test}

Scallop satay samples were placed in a sterile tube containing Lactose Broth. Several tubes were incubated for 48 hours at $35^{\circ} \mathrm{C}$, then checked for gas formation, because bacteria will ferment lactose and produce gas. If gas is not formed within 24 hours, incubation is continued for up to 48 hours. The estimator test is said to be positive if there is gas in the tube which is indicated by the floating of the Durham tube. This test detects the fermentative nature of Coliform in the sample and must be confirmed by a confirmatory test to rule out the presence of other organisms that give a positive result in lactose fermentation [17].

\subsubsection{Confirmed Test}

The positive tube obtained from the estimator test was followed by a confirmatory test. Positive samples showing gas were inoculated on Brilliant Green Lactose Broth media, then incubated at $37^{\circ} \mathrm{C}$ for 48 hours. After 48 hours, all tubes will be examined for results. If gas is produced, then this confirmatory test is declared positive and recorded to calculate the estimated number of Coliform bacteria according to the MPN table series 3 FDA-BAM tubes [17].

\subsubsection{Completed test}

Completed test was carried out by inoculating bacterial colonies on agar medium by scratching and incubating for 24 hours at $35^{\circ} \mathrm{C}$. The media used were Endo agar and Eosin Methylene Blue (EMB). Germination on this agar media causes the agar medium to become dark purple in color with a metallic copper sheen and form colonies with dark centers. The result of this MPN method is the MPN value, which is an estimate of the 
number of growth units (Growth Units) or colony forming units (Colony Forming Units) in the sample. The unit used is generally per $100 \mathrm{cc}$, the smaller the MPN value, the higher the quality of food products for consumption.

\subsection{Analysis of Cadmium (Cd)}

Samples were first weighed with a weight of about 300 grams of wet weight each (labeled), and put in a refrigerator and analyzed in the laboratory. Determination of the heavy metal content in the scallop satay samples using the Nitric Acid-Perchloric Acid Digestion method, where the sample is oxidized by acid so that the metal is dissolved. This process is also known as destruction. Standard and calibrated solutions were prepared according to the Nitric Acid-Perchloric Acid Digestion method. Analysis of the heavy metal content of Cd in samples was carried out in the laboratory using AAS (Atomic Absorption Spectro-photometer) in accordance with the Direct Air-Acetylene Flame Method with a wavelength of $228.8 \mathrm{~nm}$ (for Cd) [18].

\section{Data Analysis}

Data analysis was carried out descriptively, namely providing a description of the sample studied through the research data obtained. The total number of bacteria was transformed in logarithmic form (Log CFU/gr). Data is expressed in absolute values and in percentages using Microsoft Office Excel 2010 software and presented in tabular form.

\section{Results and Discussion}

\subsection{Sanitary Hygiene of Traders}

Based on the sanitation hygiene of blood coockle satay traders analysis (Table 1), it shows that the poor condition of personal hygiene is $46.67 \%$, the poor condition of equipment sanitation is $73.33 \%$ and the bad condition of the sales place is $80.00 \%$.

Table 1. Hygiene and sanitation of traders

\begin{tabular}{lccc}
\hline Criteria & $\begin{array}{c}\text { Personal } \\
\text { Hygiene }\end{array}$ & $\begin{array}{c}\text { Equipment } \\
\text { sanitation }\end{array}$ & $\begin{array}{c}\text { The sales place } \\
\text { sanitations }\end{array}$ \\
\hline Good & $7(46,67 \%)$ & $4(26,67 \%)$ & $3(20,00 \%)$ \\
Poor & $8(53,33 \%)$ & $11(73,33 \%)$ & $12(80,00 \%)$ \\
\hline Total & 15 & 15 & 15 \\
\hline
\end{tabular}

Causing factor of poor sanitation hygiene, among others, influenced by personal hygiene traders and food sanitation. Indicators of hand and nail hygiene are one of the causes of poor personal hygiene of traders [19]. From the observations, it was found that many traders did not wash their hands using soap and clean running water, traders only washed their hands with water in ordinary buckets and it was found that some traders only used rags to clean the dirt on their hands, even traders who did not wash their hands at all. Likewise, the poor environmental conditions at the place of sale where a lot of garbage is scattered and is inundated with washing water. These conditions can cause contamination of the shellfish satay products sold.

\subsection{Total Bacteria}

The level of bacterial contamination based on the average value of total microbes in blood coockle satay (Table 2), which is $7.22 \mathrm{Log} \mathrm{CFU} / \mathrm{gr}$, far exceeds the maximum limit of microbial contamination in processed foods that has been set based on [20] (5.00 Log CFU/g). This study indicated that poor hygiene and sanitation conditions of traders greatly affect the level of microbial contamination of blood coockle satay products

Table 2. Total bacteria of blood coockle satay

\begin{tabular}{cc}
\hline No. Sample & $\begin{array}{c}\text { Total bacteria } \\
\text { (Log CFU/gr) }\end{array}$ \\
\hline 1 & 8.64 \\
2 & 6.89 \\
3 & 7.34 \\
4 & 8.82 \\
5 & 5.24 \\
6 & 5.43 \\
7 & 7.25 \\
8 & 4.84 \\
9 & 7.69 \\
10 & 8.64 \\
11 & 8.34 \\
12 & 8.92 \\
13 & 8.54 \\
14 & 7.34 \\
15 & 5.24 \\
\hline Average & 7.22 \\
\hline
\end{tabular}

The high total microbe in blood coockle satay is mostly caused by traders not implementing proper and proper hygiene and sanitation requirements. The state of poor sanitation and hygiene condition affects the quality of food served to consumers, so it will also affect the health of consumers. If the food sanitation hygiene is poor, it can lead to health problems such as foodborne disease and cases of food poisoning [21].

\subsection{Total Coliform}

Table 3. Total Coliform in blood coockle satay

\begin{tabular}{ccc}
\hline No.Sample & $\begin{array}{c}\text { Total Coliform } \\
(\mathrm{MPN} / \mathrm{g})\end{array}$ & Status \\
\hline 1 & $>1600$ & Not eligible \\
2 & $>1600$ & Not eligible \\
3 & $>1600$ & Not eligible \\
4 & $>1600$ & Not eligible \\
5 & 13 & Not eligible \\
6 & 11 & Not eligible \\
7 & $>1600$ & Not eligible \\
8 & 21 & Not eligible \\
9 & 240 & Not eligible \\
10 & 13 & Not eligible \\
11 & 1600 & Not eligible \\
12 & $>1600$ & Not eligible \\
13 & $>1600$ & Not eligible \\
14 & 540 & Not eligible \\
15 & 11 & Not eligible \\
\hline Description: & Meets the requirements $<3$ MPN/g \\
\multicolumn{4}{c}{ Not eligible $\geq 3 \mathrm{MPN} / \mathrm{g}$} &
\end{tabular}


Coliform is a group of bacteria that is used as an indicator of sewage pollution and poor sanitation conditions for water, food, milk and dairy products. The presence of Coliform bacteria in food indicates the possibility of enteropathogenic and toxigenic microbes that are harmful to health [21].

The results (Table 3 ), showed that the contamination of Coliform bacteria in all (15) samples of blood coockle satay exceeded the maximum limit determined by [22] which was $>3 \mathrm{MPN} / \mathrm{gram}$. The highest contamination (total Coliform $>1600 \mathrm{MPN} /$ gram) was at 1, 2, 3, 4, 7, 12,13 traders; while the lowest contamination was at 11 and 15 traders (total Coliform $11 \mathrm{MPN} /$ gram).

The high total coliform in scallop satay is mostly caused by traders not implementing proper and proper hygiene and sanitation requirements. Coliform is a group of bacteria that is used as an indicator of sewage pollution and poor sanitation conditions for water, food, milk and dairy products.

\subsection{Cadmium (Cd)}

\begin{tabular}{cc} 
Tabel 4. Cadmium (Cd) content in blood coockle satay \\
\hline No Sample & Cd content $(\mathrm{mg} / \mathrm{kg})$ \\
\hline 1 & $<0.0028$ \\
2 & $<0.0028$ \\
3 & $<0.0028$ \\
4 & $0.73^{*}$ \\
5 & $0.35^{*}$ \\
6 & $<0.0028$ \\
7 & $<0.0028$ \\
8 & $<0.0028$ \\
9 & $<0.0028$ \\
10 & $0.72^{*}$ \\
11 & $<0.0028$ \\
12 & 0.02 \\
13 & $0.46^{*}$ \\
14 & $0.24^{*}$ \\
15 & 0.03 \\
\hline Note : & Theavy metal content exceeds the threshold \\
\hline
\end{tabular}

Table 9, showed that $33.33 \%$ (5 of 15 samples) of blood coockle satay samples contained Cadmium above the maximum allowable limit. The highest level of $\mathrm{Cd}$ in scallop satay was $0.73 \mathrm{mg} / \mathrm{kg}$, and the lowest level was $<0.0028 \mathrm{mg} / \mathrm{kg}$. The threshold set by [8] regarding $\mathrm{Cd}$ heavy metal contamination in processed food is allowed to be $<0.1 \mathrm{mg} / \mathrm{kg}$, so it is necessary to reexamine the source of the contaminant and need to be vigilant in its consumption patterns.

The presence of heavy metal content of $\mathrm{Cd}$ in blood coockle satay can be influenced by several factors, including the $\mathrm{Cd}$ content in fresh scallops as raw material for making scallop satay, as well as improper processing of scallop satay. [23] reported that the level of accumulation of heavy metals in fish body tissues was found in the liver, kidneys, gills and mussel meat.

The presence of Cadmium in raw shellfish is not only influenced by the location of catching mussels which are at the source of heavy metal pollution, but also by the length of time exposed to shellfish by waste containing $\mathrm{Cd}$ metal. The longer exposure to heavy metals, the more bioaccumulation that occurs in the shellfish body will increase. The length of contact with heavy metal contamination can be seen through the increasing size of the shells. The location of catching shellfish in the waters is one of the most supportive factors for the presence of heavy metal content in shellfish. The further away the oyster fishing location is from the pollutant location, the lower the accumulated pollutant content [24]. Cadmium in the human body can cause damage to the liver, kidneys, lungs, bones, and is a carcinogen

\section{Conclusion}

Total bacteria avarage of blood coockles satay is 7.22 Log CFU/gr far exceeds the maximum limit of microbial contamination in processed foods that has been set based on Food and Drug Supervisory Agency Regulation No. 13 of 2019 (5.00 Log CFU/g). Coliform bacterial contamination exceeds the maximum limit set by the Food and Drug Supervisory Agency of the Republic of Indonesia in 2009 (>3 MPN/gram). As many as of $33.33 \%$ samples contain Cadmium exceeded the maximum limit set by the Food and Drug Supervisory Agency of the Republic of Indonesia in 2017 (>0.1 $\mathrm{mg} / \mathrm{kg}$ ). The high total bacteria and total Coliform was caused because most of the traders did not apply proper and proper hygiene and sanitation requirements.

The research was financially supported by the Research and Community Service Institude of Universitas Pembangunan Nasional "Veteran" Jawa Timur through Riset Dasar (RISDA) Lanjutan scheme for the 2020.

\section{References}

[1] Peraturan Pemerintah RI No. 86 Tahun 2019 tentang Keamanan Pangan

[2] Undang-Undang Republik Indonesia No. 18 Tahun 2012 tentang Pangan

[3] R. Adriyani, and T. Mahmudiono, "Kadar Logam Berat Cadmium, Protein dan Organoleptik pada Daging Bivalvia dan Perendaman Larutan Asam Cuka," Jurnal Media Eksakta, VIII (2), pp. 152-161, (2009).

[4] Y.A. Anggraeny, “Analisis Kandungan Logam Berat $\mathrm{Pb}, \mathrm{Cd}$, dan $\mathrm{Hg}$ pada Kerang Darah (Anadara granosa) di Perairan Bojonegara, Kecamatan Bojonegara, Kabupaten Serang”. Skripsi. Departemen Manajemen Sumberdaya Perairan Fakultas Perikanan dan Ilmu Kelautan IPB- Bogor, (2010).

[5] A. Daud, A.A, M. Dullah, A. Malongi, "Risk Management of Cadmium (Cd) Due to Leiognathus sp, Portunus pelagicus, Anadara sp and Penaeus sp consumption among community in Tallo Subdistric, Makassar, Indonesia," International Journal of Scientific and Research Publication. 3(11), (2013).

[6] I. Kusuma, "Kandungan Logam Berat $\mathrm{Pb}, \mathrm{Cu}$, $\mathrm{Cd}$, dan Hg pada Kerang Darah Anadara granosa (Linnaeus, 1758) di Perairan Pesisir Kabupaten Tangerang". Skripsi Departemen Manajemen 
Sumber Daya Perairan Fakultas Perikanan Dan Ilmu Kelautan Institut Pertanian Bogor, (2014).

[7] W.L. Septiani, W.L. "Analisis Kandungan Timbal ( $\mathrm{Pb})$, Kadmium (Cd) dan Seng ( $\mathrm{Zn}$ ) pada Kerang Darah (Anadara granosa L.) di Pantai Prigi Trenggalek dan Pantai Kenjeran Surabaya. Skripsi. Program Studi Teknik Lingkungan. Fakultas Sains dan Teknologi. Universitas Airlangga. Surabaya, (2018).

[8] Peraturan Kepala Badan Pengawas Obat dan Makanan Republik Indonesia Nomor 23 Tahun 2017 tentang Batas Maksimum Cemaran Logam Berat Dalam Pangan Olahan

[9] T.D. LeCoultre, "A Meta-analysis and Risk Assesment of Heavy Metal Uptake In Common Garden Vegetables". Thesis. Faculty of the Department of Environmental Health, East Tennessee State University, US. 64 pp., (2001).

[10] I. Lehmann, U. Sack and J. Lehmann, " Metal Ions Affecting the Immune System". Met. Ions Life Sci, 8, 157-185, (2011).

[11] P. Widyastuti, "Bahaya Bahan Kimia pada Kesehatan Manusia dan Lingkungan", Penerbit Buku Kedokteran, Jakarta, (2006).

[12] A. Setiawan, "Perubahan Kandungan LogamLogam dalam Kerang Darah (Anadara Granosa) Selama Proses Pembuatan dan Pemanasan Ulang Sate Kerang dan Evaluasi Risiko Konsumsinya", Doctoral Dissertation, Prodi Teknologi Pertanian Unika Soegijapranata), (2010).

[13] H. Widowati, W.S. Sulistiani, and A. Sutanto, "Pengaruh Proses Pengolahan terhadap Kadar Logam Berat dan Kadar Gizi pada Kacang Panjang", Bioedukasi (Jurnal Pendidikan Biologi), 8(2), pp.171-175, (2017).

[14] U. Khasanah, "Pemeriksaan Bakteri Escherichia colis pada Sate Kerang Darah (Anadara Granosa) yang Dijual Di Pasar Tradisional Kota Surabaya”. Skripsi. Universitas Airlangga, 2018.

[15] R. Yulistiani, D. Praseptiangga, Supyani and Sudibya. "Contamination level and prevalence of foodborne pathogen Enterobacteriaceae in broiler and backyard chicken meats sold at traditional markets in Surabaya, Indonesia". Malays. Appl. Biol. 48(3): 95-103. (2019).

[16] R. Lawley, L. Curtis, and J. Davis, "The Food Safety Hazard". London : RSC Publishing, 2008.

[17] R. Blodgett, "BAM Appendix 2: Most Probably Number from Serial Dilutions. U. S. Food and Drug Administration". (2010).

[18] E.W. Rice, R.B. Baird, A.D. Eaton., L.S. Clesceri, "Standard Method for The Examination of Water and Wastewater". Ed ke-22. New York (US): APHA, (2012).

[19] S.I. Trigunarso, "Hygiene Sanitasi dan Perilaku Penjamah Makanan dengan Angka Kuman pada Makanan Jajanan di Lingkungan Sekolah", Jurnal Kesehatan, 11(1), pp.115-124, (2020).

[20] Peraturan Badan Pengawas Obat dan Makanan. Nomor 13 Tahun 2019 tentang Batas Maksimal Cemaran Mikroba Dalam. Pangan Olahan.
[21] N.L.P.M. Widiyanti, and N.P. Ristiati, "Analisis Kualitatif Bakteri Coliform Pada Depu Air Minum Isi Ulang Di Kota Sibgaraja Bali”, Jurnal Ekologi Kesehatan, vol. 3, no.1, pp..68, (2004).

[22] Badan Pengawas Obat dan Makanan Republik Indonesia Nomor Hk.00.06.1.52.4011, (2009), "Penetapan Batas Maksimum Cemaran Mikroba dan Kimia dalam Makanan", pp. 1-28, Regulasi Pangan BPOM No HK.00.06.1.52.4011

[23] Q. Ahmed, D. Khan, E. Naeema, "Concentration of heavy metals ( $\mathrm{Fe}, \mathrm{Mn}, \mathrm{Zn}, \mathrm{Cd}, \mathrm{Pb}$, and $\mathrm{Cu}$ ) in Muscle, Liver dan Gills of Adult Sardinella albelia (Valenciennes 1847) from gwadar water of Balochistan", Pakistan. Federal Urdu University Art Science and Technology, Journal of Biology. 4(2) :195-204, (2014).

[24] M.M. Susanti, and M. Kristiani, "Analisis Kandungan Logam Berat Timbal $(\mathrm{Pb})$ dalam Kerang (Anadara sp.) yang beredar di Kota Semarang", IJMS-Indonesian Journal on Medical Science, 3(1). (2016). 